\title{
IMPLEMENTASI KAHOOT! SEBAGAI INOVASI PEMBELAJARAN
}

Irwan

PPKn, Universitas Negeri Padang

irwanhamdi@fis.unp.ac.id

\section{ABSTRAK}

Penelitian ini bertujuan untuk menganalisis pemanfaatan platform Kahoot! sebagai media dalam pembelajaran Pendidikan Kewarganegaraan. Kahoot! merupakan web tool daring berbasis pendidikan yang dapat digunakan sebagai media asesmen mahasiswa. Metode penelitian yang digunakan yaitu metode campuran (mixed method) antara kualitatif dan metode kuantitatif. Metode kualitatif digunakan dalam menelaah pemanfaatan Kahoot! sebagai media pembelajaran perkuliahan. Sementara untuk mengukur efektivitas Kahoot! sebagai media pembelajaran maka digunakan metode kuantitatif. Objek penelitian ini yaitu mahasiswa MKWU Pendidikan Kewarganegaraan Universitas Negeri Padang sebanyak dua kelas pada semester Januari-Juni 2018. Data dikumpulkan melalui observasi langsung, wawabcara informan, tes penguasaan materi sebelum dan sesudah penggunaan Kahoot!, serta penyebaran kuesioner terhadap responden. Melalui penelitian ini akan dideskripsikan tata cara pemanfaatan kahoot! sebagai media pembelajaran bagi dosen terhadap mahasiswa sehingga dapat diukur nilai manfaat Kahoot! tersebut. Penelitian ini juga menghasilkan kesimpulan apakah Kahoot! efektif dalam sebagai media pembelajaran dalam menunjang proses belajar dan mengajar. Luaran penelitian ini diharapkan dapat menjadi draft artikel yang akan disubmit melalui jurnal lokal.

\section{Kata kunci: Kahoot!, Media, Media Pembelajaran.}




\section{PENDAHULUAN}

Kebutuhan teknologi informasi di zaman globalisasi ini tidak dapat dikesampingkan dan menjadi suatu kebutuhan yang vital. Penguasaan teknologi informasi sudah menjadi "gaya hidup" bagi sebagian besar masyarakat terutama para pemuda. Seiring dengan tatanan dunia yang sudah beralih dari ranah konvensional menjadi ranah digital, maka perkembangan teknologi informasi dan komunikasi telah merambah ke dunia pendidikan. Bagi seorang pendidik, penguasaan dan pengetahuan teknologi (technological knowledge) merupakan kompetensi yang harus dikuasai guna mendukung peningkatan proses pembelajaran. Sementara bagi peserta didik, penguasaan teknologi dapat menunjang proses berfikir dan penguasaan Ilmu Pengetahuan.

Perkembangan media pembelajaran di Perguruan Tinggi perlahan diikuti oleh inovasiinovasi yang bertujuan untuk memudahkan proses pembelajaran. Misalnya keberadaan papan tulis sudah dapat dikomplementer dengan LCD proyektor, sehingga dosen harus menuliskan materi didepan kelas. Kondisi seperti ini dapat disebutkan sebagai proses pembelajaran berbasis teknologi. Pemanfaatan teknologi untuk menunjang proses pembelajaran adalah suatu hal yang lazim dan akan memberikan banyak dampak positif. Inovasi teknologi tidak berhenti sampai disitu. Perkembangan ilmu pengetahuan pada gilirannya diikuti oleh perkembangan teknologi yang berorientasi masa depan. Mewujudkan pendidikan yang berkualitas erat kaitannya dengan pendidik yang berkualitas. Pada tahun 2009, sebuah laporan dengan judul "Learning for the 21 $1^{\text {st }}$ Century" mempublikasikan "Framework for $21^{\text {st }}$ Century Learning" (Marzano \& Heflebower, 2012) menjelaskan tentang empat kompotensi atau bidang yang harus dikuasai oleh peserta didik yang meliputi "1) core subject and $21^{\text {st }}$ century themes, 2) learning and innovative skills, 3) information, media and technology skills and 4) life and career skills". Merujuk kepada konsep tersebut dapat diketahui bahwa penerapan teknologi dalam pembelajaran harus disesuaikan dengan tema pada abad 21. Fenomena pada abad 21 yaitu era serba digital, sehingga ranah pendidikan perlahan harus beralih ke aspek digital (digitalisasi).

Kenyataan yang terjadi saat ini, perkuliahan cenderung masih bersifat konvensional. Sebagian tenaga pendidik masih nyaman dengan proses pembelajaran yang konvensional sehingga perubahan paradigma pada proses pembelajaran yang konvensional menuju digitalisasi perlu dilakukan. Salah satunya pada mata kuliah Pendidikan Kewarganegaraan sebagai mata kuliah wajib di perguruan tinggi. Permasalahan yang dihadapi dalam proses pembelajaran adalah mahasiswa merasa bosan terhadap materi yang disampaikan dosen. Selain itu, lemahnya interaksi yang terjadi dalam pembelajaran. Hal tersebut ditunjukkan dengan terjadinya komunikasi satu arah yaitu Dosen kepada Mahasiswa. Sehingga dibutuhkan metode ataupun media yang dapat meningkatkan kualitas pembelajaran. Salah satu inovasi teknologi yang dapat diimplementasikan dalam proses pembelajaran yaitu penggunaan platform Kahoot!. Kahoot! merupakan salah satu web tool yang menyediakan layanan 
permainan daring berbasis pendidikan. Platform gratis ini memudahkan dosen untuk melaksanakan kuis/ujian tanpa perlu mendikte didepan kelas dan mahasiswa juga tidak perlu menjawab di lembar jawaban seperti biasanya. Dosen cukup menampilkan soal/materi ujian via laptop yang ditampilkan melalui layar LCD sementara mahasiswa memberikan jawaban melalui telepon genggam masingmasing. Saat kuis berlangsung, laman Kahoot! akan langsung menampilkan jawaban yang benar atau salah sesuai dengan soal berikut skor tertinggi yang dilihat dari peserta yang menjawab paling cepat dan benar. Hal ini dapat menunjang daya kompetisi mahasiswa dalam menjawab pertanyaan yang diberikan dosen. Ada prasyarat agar media kuis interaktif Kahoot! dapat dilakukan yaitu ketersediaan aliran listrik, piranti laptop, infocus, telepon genggam, serta yang paling penting adalah ketersediaan koneksi internet.

Pemanfaatan Kahoot! sebagai media pembelajaran diharapkan dapat menjadi alternatif bagi dosen dan mahasiswa untuk membangun suasana perkuliahan menjadi lebih menarik untuk diikuti. Perkuliahan yang awalnya cenderung kaku dan monoton akan beralih kepada suasana kelas yang riang mengikuti pola Kahoot! tersebut. Pemanfaatan media Kahoot! sejalan dengan amanat era digitalisasi di Perguruan Tinggi. Oleh karena itu peneliti tertarik menganalisis Kahoot! sebagai media dalam pembelajaran dan efektivitas dari penggunaan media tersebu. Bagaimana pemanfaatan Kahoot! sebagai media pembelajaran

Pendidikan Kewarganegaraan serta Bagaimana efektivitas Kahoot! sebagai media dalam pembelajaran Pendidikan Kewarganegaraan.

\section{TINJAUAN PUSTAKA}

\section{A. Kajian Teoritis}

\section{A.1 Media Pembelajaran}

Secara harfiah, media berarti perantara atau pengantar pesan dari pemberi pesan kepada penerima pesan. Carol Bertram, dkk (2010) menjelaskan fungsi media alat yang digunakan untuk menyampaikan suatu hal, bisa berupa musik, informasi, pendidikan maupun pengaruh (Carol Bertram,dkk2010:19). Dalam ranah pendidikan, Gerlach \& Ely (1971) mengatakan bahwa media secara garis besar adalah manusia, materi, atau kejadian yang membangun kondisi yang membuat siswa mampu memperoleh pengetahuan, keterampilan, atau sikap. Oleh karena itu dapat dikatakan bahwa media membantu pendidik dalam melaksanakan proses pembelajaran agar pesan yang diberikan dapat diterima dengan baik oleh peserta didik sehingga dapat terjadi proses belajar-mengajar. Hamalik (1986) mengemukakan bahwa penggunaan media pembelajaran dalam proses belajar mengajar dapat membangkitkan motivasi dan rangsangan kegiatan belajar dan bahkan dapat membawa pengaruh psikologis terhadap siswa. Selain itu, media pembelajaran dapat menjadi alternatif dalam 
membangkitkan motivasi dan minat siswa, meningkatkan pemahaman, menyajikan data dengan menarik dan memadatkan informasi.

Menurut Arief Saidiman, dkk, kegunaan media dalam proses belajar mengajar secara umum sebagai berikut:

(1) Memperjelas penyajian pesan agar tidak terlalu bersifat verbalitas

(2) Mengatasi keterbatasan ruang, waktu dan daya indera

(3) Penggunaan media pendidikan secara tepat dan bervariasi dapat mengatasi sikap pasif anak didik

Beberapa jenis media pembelajaran yang lazim dipakai adalah:

\section{Media grafis}

Media grafis merupakan media visual yang berfungsi untuk menyalurkan pesan dari sumber ke penerima pesan menggunakan indera penglihatan. Pesan yang akan disampaikan dituangkan ke dalam simbol-simbol komunikasi visual. Simbolsimbol tersebut perlu dipahami benar artinya agar proses penyampaian pesan dapat berhasil dan efisien. Selain fungsi umum tersebut, secara khusus grafis berfungsi pula untuk menarik perhatian, memperjelas sajian ide, mengilustrasikan atau menghiasi fakta yang mungkin akan cepat dilupakan atau diabaikan bila tidak digrafiskan. Terdapat beberapa jenis media grafis yaitu: gambar/foto, sketsa, diagram, bagan/chart, grafik, kartun, poster, papan flanel, serta papan buletin.

\section{Media Audio/Radio}

Media audio berkaitan dengan indera pendengaran. Pesan yang akan disampaikan dituangkan dalam lambang-lambang auditif, baik verbal maupun non verbal. Beberapa jenis media yang bisa dikelompokkan dalam media audio yaitu radio. Sebagai suatu media, radio mempunyai beberapa kelebihan jika dibandingkan dengan media yang lain, yaitu harga yang relatif murah dan fleksibel.

\section{Media Proyeksi diam}

Media proyeksi diam (still proyected medium) mempunyai persamaan dengan media grafik dalam arti menyajikan rangsangan-rangsangan visual. Selain itu, bahan-bahan grafis banyak sekali dipakai dalam media proyeksi diam. Perbedaan yang jelas di antara mereka adalah pada media grafis dapat secara langsung berinteraksi dengan pesan media yang bersangkutan pada media proyeksi, pesan tersebut harus diproyeksikan dengan proyektor agar dapat dilihat oleh sasaran terlebih dahulu. Adakalanya media jenis ini disertai rekaman audio, tapi ada pula yang hanya visual saja. Beberapa jenis media proyeksi diam yaitu: film bingkai, film 
rangkai, media transparansi, mikrofis, Film, Film gelang, Televisi, Video serta Permainan dan Simulasi.

Penelitian media Kahoot! ini dapat digolongkan sebagai media proyeksi diam dalam konteks permainan. Permainan adalah setiap kontes antara pemain yang berinteraksi satu sama lain dengan mengikuti aturan-aturan tertentu untuk mencapai tujuan-tujuan tertentu. Setiap permainan harus mempunyai empat komponen utama yaitu adanya pemain, lingkungan dimana para pemain berinteraksi aturan-aturan, serta tujuan-tujuan tertentu yang ingin dicapai. Pola permainan adalah satu cara dalam meningkatkan gairah belajar dan komunikasi langsung dua arah adalah dengan menyediakan media pembelajaran dalam pola permainan. Sebab, secara naluriah, usia pendidikan dari tingkat dasar hingga perguruan tinggi menyukai konsep permainan.

Sharon E.Smaldino, dkk di dalam bukunya instructional technology and media learning menyatakan bahwa ada beberapa alasan mengapa pola asesmen dengan permainan menjadi menarik, yaitu:

1. Atraktif, peserta didik akan lebih atraktif karena mereka dibawa ke ranah yang sangat disukai yaitu pola permainan.

2. Kebaruan, berangkat dari rutinitas yang normal, pola permainan memberikan nuansa baru dalam proses pembelajaran.

3. Suasana yang rileks.

4. Peserta didik tidak bosan.

\section{A.2 Kahoot! Sebagai Media Pembelajaran}

Kahoot! merupakan sebuah laman daring yang sangat edukatif karena menyediakan fitur-fitur yang dapat digunakan sebagai media dalam proses pembelajaran. Kahoot! awalnya merupakan sebuah joint project antara tim yang beranggotakan Johan Brand, Jamie Brooker, Morten Versvik dengan Norwegian University of Technology and Science pada bulan Maret 2013. Enam bulan setelah proyek tersebut selesai, Kahoot! dilempar ke publik dan menjadi laman permainan edukatif yang tidak berbayar dan dapat diakses siapapun terutama para pendidik dan peserta didik dengan prasyarat adanya koneksi internet. Kahoot! menyediakan 2 laman yang berbeda untuk penggunanya. Pendidik yang akan memberikan asesmen dapat mengakses https://Kahoot.com/ sementara peserta didik sebagai peserta dapat mengakses https://kahoot.it/.

Dengan laman https://Kahoot.com/, pendidik dapat melakukan beberapa aktivitas diantaranya pendaftaran (sign-up), masuk ke laman pribadi (log-in), memilih fitur yang tersedia yaitu kuis, diskusi maupun survei. Setelah memilih salah satu fitur maka pendidik dapat mulai memasukkan daftar pertanyaan berikut 
jawaban, durasi waktu untuk menjawab, dan skor untuk tiap jawaban yang benar. Daftar pertanyaan yang sudah dimasukkan dapat disimpan, diubah, dihapus, ditambahkan serta digunakan dalam proses asesmen secara berulang tanpa ada batasan penggunaan. Setiap kelompok pertanyaan memiliki PIN yang nantinya akan dimasukkan oleh peserta didik saat asesmen dilakukan. Setelah permainan selesai maka Kahoot! otomatis menampilkan skor untuk semua peserta yang dapat diunduh dan disimpan secara pribadi.

Peserta didik yang mengakses https://Kahoot.it/ baik melalui telepon genggam atau komputer pribadi akan menampilkan laman yang berbeda dengan pendidik. Dimana tampilan di layar peserta didik adalah permintaan memasukkan "game pin", dan "nick name". Game PIN adalah semacam kode soal berupa 6 digit angka yang dapat diperoleh dari pendidik dan nick name merupakan nama tiap-tiap peserta yang akan ikut asesmen melalui media Kahoot!. Dengan mengisi kedua kolom diatas maka peserta didik sudah terdaftar sebagai peserta asesmen secara otomatis. Setelah itu peserta didik cukup menjawab tiap-tiap pertanyaan yang ditampilkan di layar komputer pendidik melalui gadget masing-masing. Sisi paling menarik saat pelaksanaan Kahoot! Yaitu untuk setiap soal yang sudah dijawab, layar komputer pendidik akan langsung menampilkan jawaban yang benar, jawaban salah dan skor tiap-tiap peserta sehingga peserta didik dapat mengetahui salah atau benar jawaban yang diberikan dan berkompetisi dalam menjawab pertanyaan berikutnya. Kahoot! merupakan inovasi bidang teknologi yang edukatif dan dapat diimplementasikan dalam proses pembelajaran. Salah satunya dalam Mata Kuliah Pendidikan kewarganegaraan yang merupakan mata kuliah wajib bagi seluruh mahasiswa di Perguruan Tinggi.

\section{B. Penelitian yang Relevan}

Sebuah penelitian biasanya berangkat dari pengamatan terhadap suatu masalah atau isu terkini di lingkungan sekitar sehingga memiliki unsur kebaruan. Namun tidak menutup kemungkinan suatu penelitian sudah pernah dilakukan sebelumnya oleh pihak lain. Tentu saja terdapat perbedaan baik dari sisi variabel, objek penelitian, dan teori yang digunakan. Peneliti menemukan beberapa penelitian yang sejenis dengan penelitian ini. Berikut ini beberapa penelitian sejenis yang pernah dilakukan terkait dengan pengembangan media Kahoot! dalam proses pembelajaran: 
Tabel 2

Penelitian Terdahulu

\begin{tabular}{|c|c|c|c|c|c|}
\hline No & Nama & Judul Penelitian & $\begin{array}{l}\text { Tujuan } \\
\text { Penelitian }\end{array}$ & Hasil Penelitian & Keterangan \\
\hline 1 & $\begin{array}{l}\text { Huseyin } \\
\text { Bicen dan } \\
\text { Senay } \\
\text { Kocakoyun }\end{array}$ & $\begin{array}{l}\text { Determination } \\
\text { of university } \\
\text { students' most } \\
\text { preferred } \\
\text { mobile } \\
\text { application for } \\
\text { gamification }\end{array}$ & $\begin{array}{l}\text { Menganalisis } \\
\text { dan } \\
\text { menentukan } \\
\text { aplikasi } \\
\text { permainan } \\
\text { yang paling } \\
\text { diminati } \\
\text { mahasiswa } \\
\text { dalam proses } \\
\text { pembelajaran }\end{array}$ & $\begin{array}{lr}\text { Kahoot! menjadi } \\
\text { aplikasi } \\
\text { paling yang } \\
\text { dipilih banyak } \\
\text { dioperasikan dan } \\
\text { mahasiswa dalam } \\
\text { proses belajar. }\end{array}$ & $\begin{array}{l}\text { World } \\
\text { Journal on } \\
\text { Educational } \\
\text { Technology: } \\
\text { Current } \\
\text { Issues Vol 9, } \\
\text { Issue 1, } \\
\text { (2017) 18-23 }\end{array}$ \\
\hline 2 & $\begin{array}{l}\text { Ryan } \\
\text { Dellos }\end{array}$ & $\begin{array}{l}\text { Kahoot! a digital } \\
\text { game resource } \\
\text { for learning }\end{array}$ & $\begin{array}{l}\text { Menganalisis } \\
\text { penggunaan } \\
\text { Kahoot! } \\
\text { sebagai cara } \\
\text { praktis } \\
\text { mendorong } \\
\text { proses } \\
\text { pembelajaran } \\
\text { yang berbasis } \\
\text { permainan }\end{array}$ & $\begin{array}{l}\text { Kahoot! sangat } \\
\text { efektif dalam } \\
\text { mengintegrasikan } \\
\text { proses } \\
\text { pembelajaran dan } \\
\text { menunjang } \\
\text { kompetisi peserta } \\
\text { didik }\end{array}$ & $\begin{array}{l}\text { Journal of } \\
\text { Instructional } \\
\text { Technology } \\
\text { and } \\
\text { Distance } \\
\text { Learning, } \\
\text { Volume } 12 \\
\text { Number 4, } \\
\text { April } 2015 .\end{array}$ \\
\hline 3 & $\begin{array}{l}\text { Fitri } \\
\text { Rofiyarti, } \\
\text { Anisa } \\
\text { Yunita Sari }\end{array}$ & $\begin{array}{l}\text { TIK untuk } \\
\text { AUD: } \\
\text { Penggunaan } \\
\text { Platform } \\
\text { "Kahoot!” } \\
\text { Dalam } \\
\text { Menumbuhkan } \\
\text { Jiwa Kompetitif } \\
\text { Dan Kolaboratif } \\
\text { Anak }\end{array}$ & $\begin{array}{l}\text { Menganalisis } \\
\text { Kahoot! } \\
\text { sebagai } \\
\text { alternatif } \\
\text { dalam } \\
\text { meningkatkan } \\
\text { perkembangan } \\
\text { emosional } \\
\text { anak }\end{array}$ & $\begin{array}{l}\text { Kahoot! Dapat } \\
\text { digunakan } \\
\text { sebagai alternatif } \\
\text { dalam } \\
\text { meningkatkan } \\
\text { perkembangan } \\
\text { emosional anak, } \\
\text { namun harus } \\
\text { tetap diawasi } \\
\text { untuk mencegah } \\
\text { kecanduan } \\
\text { gadget. }\end{array}$ & $\begin{array}{l}\text { PEDAGOGI: } \\
\text { Jurnal Anak } \\
\text { Usia Dini } \\
\text { dan } \\
\text { Pendidikan } \\
\text { Anak Usia } \\
\text { Dini Volume } \\
3 \text { Nomor 3b } \\
\text { Desember } \\
\text { 2017 P-ISSN: } \\
\text { 2599-0438; } \\
\text { E-ISSN: } \\
\text { 2599-042X }\end{array}$ \\
\hline
\end{tabular}




\section{METODE PENELITIAN}

Penelitian ini merupakan penelitian analisis dengan menggunakan metode campuran (mixed method) yaitu kualitatif dan kuantitatif yaitu melihat manfaat dan efektivitas Kahoot! sebagai media dalam pembelajaran pendidikan kewarganegaraan. Melalui metode kualitatif dapat dianalisis pemanfaatan Kahoot! sebagai media alternatif dalam proses pembelajaran. Sementara dengan metode kuantitatif, peneliti akan melihat apakah Kahoot! efektif dijadikan sebagai media pembelajaran pada kelas Pendidikan Kewarganegaraan.

\section{A. Lokasi Penelitian}

Lokasi penelitian ini berada di kelas Mata Kuliah Pendidikan Kewarganegaraan Universitas Negeri Padang.

\section{B. Populasi dan Sampel}

Populasi penelitian ini adalah mahasiswa Universitas Negeri Padang yang mengambil Mata Kuliah Wajib Umum Pendidikan Kewarganegaraan pada semester Januari-Juni 2018 sejumlah dua kelas. Teknik sampling yang digunakan pada penelitian ini adalah Purposive Sampling yaitu mengambil sebagian sampel yang mewakili populasi secara keseluruhan.

\section{Variabel Penelitian}

Variabel yang digunakan dalam penelitian ini adalah variabel tunggal yaitu pemanfaatan Kahoot! Sebagai media pembelajaran di kelas Pendidikan Kewarganegaraan.

\section{Responden Penelitian}

Responden untuk penelitian ini sama dengan populasinya yaitu mahasiswa yang mengambil mata kuliah Pendidikan Kewarganegaraan pada semester Januari-Juni 2018 sebanyak 100 orang dalam 2 kelas. 


\section{E. Rancangan Penelitian}

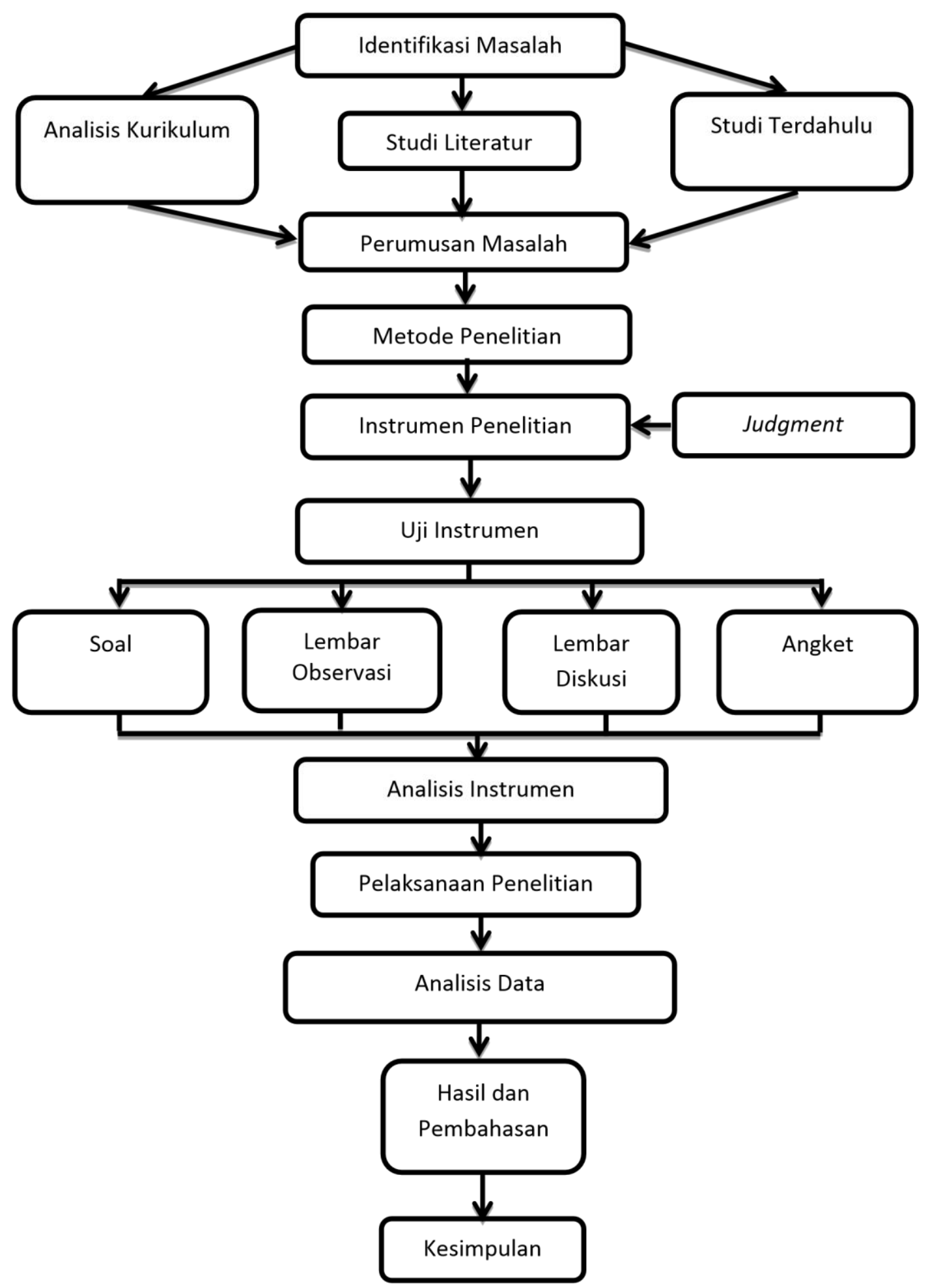

\section{F. Teknik Pengumpulan Data}

Teknik pengumpulan data merupakan cara-cara yang dapat digunakan oleh peneliti untuk mengumpulkan data. Teknik yang dipergunakan untuk penelitian ini adalah sebagai berikut: 


\section{Observasi}

Teknik observasi lapangan dilakukan untuk mendapatkan data yang aktual dan langsung dengan melakukan pengamatan dan pencatatan secara sistematis terhadap gejala atau fenomena yang ada pada objek penelitian. Dalam hal ini dilakukan dengan cara pengamatan langsung dilapangan dengan menggunakan lembar observasi untuk melihat dan mengamati keberlangsungan pemanfaatan Kahoot! dalam proses pembelajaran di kelas Pendidikan Kewarganegaraan.

\section{Wawancara}

Teknik wawancara dilakukan terhadap informan penelitian untuk mendapatkan data secara langsung. Informan akan diberikan beberapa pertanyaan secara langsung berkaitan dengan manfaat Kahoot sebagai media pembelajaran. Jawaban-jawaban yang diberikan oleh informan kemudian disusun secara sistematis, kemudian dianalisis untuk menjawab pertanyaan penelitian.

\section{Tes Penguasaan Materi}

Tes yang digunakan dalam penelitian ini adalah tes pilihan ganda. Pemberian tes dilakukan pada saat pembelajaran berlangsung. Tes dilaksanakan di setiap pertemuan perkuliahan. Pertanyaan yang diberikan akan disesuaikan dengan materi perkuliahan yang sudah dipelajari pada pertemuan sebelumnya.

\section{Kuesioner}

Kuesioner menurut Sugiyono (2014, hlm. 142) merupakan teknik pengumpulan data yang dilakukan dengan cara memberi seperangkat pertanyaan pada media Kahoot! kepada responden untuk dijawab (Survei).

\section{G. Teknik Analisis Data}

Alat tes penelitian dilakukan uji coba setelah selesai disusun untuk melihat kualitas soal yang terdiri dari validitas, reliabilitas, daya pembeda dan tingkat kesukaran soal.

\section{Uji Validitas}

Pengujian validitas alat ukur kemampuan penalaran dilakukan untuk mengetahui ketepatan instrumen dalam mengukur kemampuan penalaran peserta didik sesuai dengan indikator yang telah ditetapkan. Menurut Sugiyono (2014, hlm. 121) valid berarti instrumen tersebut dapat digunakan untuk mengukur apa yang seharusnya diukur. Uji validitas dalam penelitian ini menggunakan rumus Pearson Product Moment dengan rumusan sebagai berikut: 
Keterangan:

rxy : Koefisien korelasi dua variabel yang dikorelasikan

N : Jumlah responden

$\sum \mathrm{Y} \quad$ : Jumlah skor total (seluruh item)

$\sum X \quad$ : Jumlah skor item

$\sum \mathrm{Y}^{2} \quad$ Jumlah kuadrat skor total

$\sum X^{2} \quad$ : Jumlah kuadrat skor item

Kriteria pengujian apabila $r_{\text {hitung }}>r_{\text {tabel }}$ dengan $a=0,05$ maka item soal tersebut dinyatakan valid, dan sebaliknya apabila $\mathrm{r}_{\text {hitung }}<\mathrm{r}_{\text {tabel }}$ maka item soal tersebut dinyatakan tidak valid. Pengujian validitas dibantu dengan program SPSS versi 2.1 Pearson Correlation.

2. Uji Reliabilitas

Instrumen dikatakan reliable apabila instrumen yang dibuat mempunyai hasil yang sama dalam pengukuran. Uji reliabilitas tes kemampuan penalaran dilakukan dengan perhitungan Alpha (Ridwan, 2005, hlm. 165). Rumus yang digunakan adalah sebagai berikut: Keterangan:

: Reliabilitas instrumen

K : Banyaknya butir soal

$\sum \quad$ : Jumlah varian butir

: Varian total

Selanjutnya nilai $\mathrm{r}$ yang diperoleh dari perhitungan tersebut ditafsirkan dengan menggunakan interpretasi nilai $\mathrm{r}$ dari Guilford pada tabel berikut:

Tabel 3

Interpretasi Koefisien Reliabilitas

\begin{tabular}{|c|c|}
\hline Nilai $\mathbf{r}$ & Interpretasi \\
\hline $\mathrm{r} \leq 0,20$ & Derajat reliabilitas sangat rendah \\
\hline $0,20<\mathrm{r} \leq 0,40$ & Derajat reliabilitas rendah \\
\hline $0,40<\mathrm{r} \leq 0,60$ & Derajat reliabilitas sedang \\
\hline $0,60<\mathrm{r} \leq 0,80$ & Derajat reliabilitas tinggi \\
\hline $0,80<\mathrm{r} \leq 1,00$ & Derajat reliabilitas sangat tinggi \\
\hline
\end{tabular}




\section{Taraf Kesukaran}

Taraf kesukaran merupakan indeks untuk menunjukkan sukar dan mudahnya suatu soal bagi peserta didik. Besarnya rentangan indeks kesukaran dimulai dari 0,00 sampai dengan 1,0. Taraf kesukaran dapat dihitung dengan rumus sebagai berikut:

\section{Keterangan:}

P : Indeks Kesukaran

B : Banyaknya peserta didik yang menjawab soal dengan benar

Js : Jumlah seluruh peserta didik yang mengikuti tes.

Klasifikasi taraf kesukaran menurut Arifin (2011 hlm. 135) adalah sebagai berikut: Soal dengan P 0,00 - 0,30 adalah soal sukar Soal dengan P 0,31 - 0,70 adalah soal sedang Soal dengan P 0,71 - 1,00 adalah soal mudah

\section{Uji Daya Pembeda}

Daya pembeda digunakan untuk membedakan dan mengkelompokkan butir soal tes peserta didik. Pengujian tersebut dilakukan untuk mencari pembeda setiap butir soal, peserta didik dikelompokkan menjadi skor kelompok atas dan skor kelompok bawah. Rumusnya adalah sebagai berikut:

Keterangan:

DP : Indeks daya pembeda

JBA : Jumlah skor kelompok atas

$\mathrm{JB}_{\mathrm{B}} \quad$ : Jumlah skor kelompok bawah

: Jumlah skor ideal kelompok

$\mathrm{JS}_{\mathrm{A}}$ atas

Hasil dari uji daya beda alat tes kemampuan penalaran peserta didik dijelaskan pada tabel klasifikasi daya pembeda menurut Arikunto sebagai berikut:

Tabel 4

Kategori Daya Pembeda

\begin{tabular}{|c|c|}
\hline Batasan & Kategori \\
\hline $\mathrm{D} \leq 0.00$ & Sangat Jelek \\
\hline $0.00 \leq \mathrm{D}<0.20$ & Jelek \\
\hline $0.20 \leq \mathrm{D}<0.40$ & Cukup \\
\hline
\end{tabular}




\begin{tabular}{|c|c|}
\hline $0.40 \leq \mathrm{D}<0.70$ & Baik \\
\hline $0.70 \leq \mathrm{D}<1.00$ & Baik Sekali \\
\hline
\end{tabular}

Sumber: Arikunto (2012, hlm. 232)

Meningkatnya penguasaan materi mahasiswa dalam penggunaan media Kahoot! dapat diketahui dengan menggunakan gain ternormalisasi (Meltzer, 2002). Hasil perhitungan diinterpretasikan dengan menggunakan indeks gain menurut Savinainen \& Scoot sebagai berikut:

Tabel 5

Klasifikasi N-Gain Ternormalisasi

\begin{tabular}{|l|l|}
\hline Nilai N-Gain & Interpretasi \\
\hline N-Gain $>0,70$ & Tinggi \\
\hline $0,30 \leq$ N-Gain $\leq 0,70$ & Sedang \\
\hline N-Gain $<0,30$ & Rendah \\
\hline
\end{tabular}

Sumber: Kusnendi (2013, hlm. 10)

Analisis proses pembelajaran dilakukan dengan melihat hasil pengolahan data pada lembar observasi pelaksanaan pembelajaran media Kahoot!. Lembar observasi meliputi sintaks yang dilaksanakan oleh Dosen dan aktivitas belajar Mahasiswa.

\section{HASIL PENELITIAN}

Hasil uji pada kelas kontrol dan kelas eksperimen tidak menunjukkan perbedaan yang signifikan ketika diberi soal dan jawaban menggunakan metode konvensional. Namun ketika kelas eksperimen diujikan menggunakan maka hasil yang didapatkan cukup signifikan. Ada peningkatan hasil belajar mahasiswa yang diperlakukan menggunakan kahoot! daripada kelas kontrol dengan metode konvensional. Perbedaan yang dihasilkan cukup signifikan sehingga perlu agar Kahoot! diterapkan dalam perkuliahan lain demi meningkatkan kemampuan belajar dan berfikir mahasiswa.

Hasil penelitian ini menunjukkan adanya ppeningkatan dari kemampuan berfikir dan belajar mahasiswa setelah menggunakan Kahoot!. ini disebabkan oleh fitur-fitur Kahoot! yang menarik sehingga tidak membuat mereka bosan dan jenuh. Selain itu kemudahan dalam mengakses Kahoot! juga menjadi keuntungan tersendiri karena mahasiswa dapat membuka Kahoot! menggunakan telepon genggam masingmasing yang sudah telah memiliki fitur android atau iphone. Selain itu ketertarikan mahasiswa dalam menggunakan Kahoot! juga disebabkan oleh tampilan Kahoot! yang menyajikan hasil atau score untuk setiap jawaban yang benar dari setiap 
pertanyaan yang ditampilkan. Kahoot! dapat digunakan pada setiap pembelajaran apapun karena tidak ada kategori khusus dalam mengakses Kahoot! oleh karena itu dapat peneliti sebutkan bahwa Kahoot! cukup efektif sebagai media dalam pembelajaran di setiap universitas. Kahoot! menjadi inovasi yang tepat ditengah era Revolusi Industri 4.0 yang menuntut penguasaan teknologi oleh setiap lapisan masyarakat. Selain itu perlu kiranya analisis lebih jauh mengenai inovasi Kahoot! agar sesuai dengan setiap materi pembelajaran.

\section{KESIMPULAN}

Kahoot! merupakan inovasi dibidang pembelajaran di dunia. Penggunakaan Kahoot! dapat meningkatkan kemampuan berfikir dan belajar peserta didik sehingga perlu untuk dikembangkan. Sebagai jawaban atas kemajuan teknologi maka dunia pendidikan berperan penting sebagai leading sector untuk menwujudkan hal tersebut. Hal ini juga senada dengan peralihan dunia dari era konvensional menuju era teknologi dan informasi yang semakin masif dan menyentuh seluruh lapisan masyarakat serta seluruh unsur kehidupan manusia saat ini. 


\section{DAFTAR PUSTAKA}

Alvarado, Gutch \& Wollen. 1987. Learning Media: an Introduction to Media Teaching. Hampshire: Macmillan Education LTD.

Arikunto, S.2012. Prosedur Penelitian Suatu Pendekatan Praktik. Jakarta:Rineka Cipta

Bertram and friends. 2010. Using Media in Teaching. Braamfontein: SAIDE

Bicen \& Kocakoyun. Determination of university students' most preferred mobile application for gamification. World Journal on Educational Technology: Current Issues

Vol 9, Issue 1, (2017) 18-23

Dellos, Ryan. Kahoot!: a digital game resource for learning. Journal of Instructional Technology and Distance Learning, Volume 12 Number 4, April 2015.

Dron \& Anderson. 2014. Learning and Social Media. Edmonton: Athabasca University Press.

Marzano \& Heflebower, 2012. Learning for the $21^{\text {st }}$ Century "Framework for $21^{\text {st }}$ Century Learning".

Meltzer, D.E. 2002. Relation between student's problem solving performance and representation format. American Journal of Physics Vol.73 no.5

Rofiyarti dan Sari. TIK untuk AUD: Penggunaan Platform "Kahoot!" Dalam Menumbuhkan Jiwa Kompetitif Dan Kolaboratif Anak. PEDAGOGI: Jurnal Anak Usia Dini dan

Pendidikan Anak Usia Dini. Volume 3 Nomor 3b Desember 2017

Smaldino \& Russel. Technology, Media, and Learning. Ohio: Prentice Hall LAMPIRANLAMPIRAN 